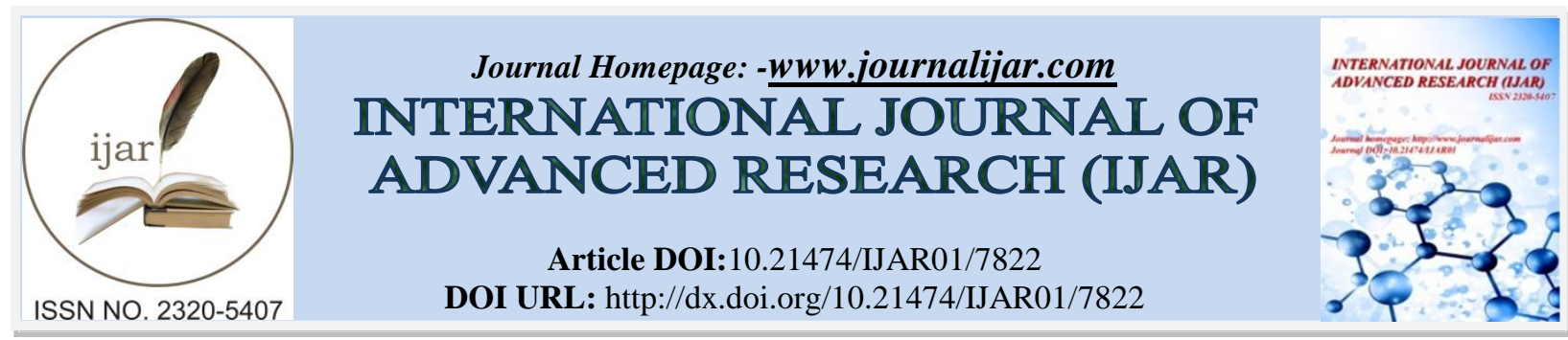

RESEARCH ARTICLE

\title{
SERUM INTERLEUKIN 13 (IL-13) LEVELS IN IRAQI CHILDREN WITH NEPHROTIC SYNDROME.
}

\author{
Ammar Basim Al-Assadi ${ }^{1}$, Nidhal A. Mohammed ${ }^{2}$ and Shatha H. Ali $^{3}$. \\ 1. College of Biotechnology / Al-Nahrain University Baghdad / Iraq. \\ 2. Al-Farahidi University college Baghdad / Iraq. \\ 3. College of Medicine / Al-Nahrain University Baghdad / Iraq.
}

\section{Manuscript Info}

Manuscript History

Received: 6 August 2018

Final Accepted: 8 September 2018

Published: October 2018

Keywords:-

Interleukin, Nephrotic syndrome, Steroid sensitive, Steroid resistance.

\begin{abstract}
The aim of this study is to compare the levels of IL-13 in children with nephrotic syndrome and healthy control children. Fifty children with NS were divided into four groups: 14 steroid sensitive infrequent relapse (SSIFR), 12 steroid sensitive frequent relapse (SSFR), 9 steroid resistance (SR) and 15 newly diagnosis (ND) compared to twenty-five unrelated healthy children. The serum IL-13 levels for NS patients and healthy control children were measured by R\&D quantitative ELISA kit. The results of mean IL-13 level in healthy children serum (205.18 \pm $2.61 \mathrm{pg} / \mathrm{ml})$ was significantly lower than children with NS $(335.50 \pm$ $40.68 \mathrm{pg} / \mathrm{ml})$. we showed serum IL-13 was increased significantly $(\mathrm{P}=$ 0.0271 ) in children with NS in compared with healthy control children, this raised in IL-13 levels could have a role in nephrotic syndrome pathogenesis.
\end{abstract}

Copy Right, IJAR, 2018,. All rights reserved.

\section{Introduction:-}

Nephrotic syndrome is an immune mediated renal disease. It is related with dysfunction of $\mathrm{T}$ cell and secondary disorder of B cell that leads to changes in scales of immunoglobulins (Roy et al., 2009; Bahbahet al.,2015). This systemic disturbance of function of $\mathrm{T}$ cell results in the production of humoral factors or lymphokines that responsible for the rise of permeability of glomerular basement membrane (Sahaliet al., 2002; Baggaet al., 2005). Nephrotic syndrome is described by huge proteinuria, edema and hypoalbuminemia, the additional features are hyperlipidemia also generally present (Bahbahet al., 2015). Hypercoagulable status, the dysregulation of fluid, imbalance in electrolyte and capability to infections can caused by large urinary wastage of serum proteins (Kim et al., 2016). Estimates on the annual incidence of nephrotic syndrome range from two to seven per 100,000 children, and prevalence from twelve to sixteen per 100,000 (Eddy and Symons, 2003).

The pathogenesis of minimal change nephrotic syndrome is not completely clear, but it is probably due to the imbalance between $\mathrm{T}$ helper 1 and $\mathrm{T}$ helper 2 cells. It appears that activation of $\mathrm{T}$ helper 2 lymphocytes has an important role inpathogenesis of minimal change disease(MCD). Cytokines of $\mathrm{T}$ helper 2 cells thathave some possible roles in the induction of proteinuriainclude IL-4, IL-10, and especially IL-13. Interleukin 13 may alter glomerular permeability and induce proteinuria in patients with MCD (Mamizadehet al., 2017).IL-13 is a cytokine that is secreted by various T-cell subsets and dendritic cells. IL-13 composite from 132 amino acids and its molecular weight is $12 \mathrm{kd}$. IL-13 shares many biologic activities with IL-4, IL-4 receptor (IL-4R) and IL-13 receptor (IL-13R) complexes share the IL-4R $\alpha$ chain needed for signal transduction (Mccormick and Heller, 2015). High production of IL-13 are by activated CD4+ TH2 cells. While, TH1 and CD8+ T cells also produce large levels of IL- 
13 (Vries, 1998). The expression of IL-13 can lead to injury of podocyte and IL-13 overexpression caused the downregulation of podocin, nephrin and dystroglycan and these proteins are critical molecules in preserving integrity of slit diaphragm (SD), and upregulation of the concurrent of IL-4R $\alpha$, IL-13R $\alpha 2$ and CD80 in IL-13transfected rats (Kim et al., 2016).

Another studies have identified that increased IL-13 expression can lead to podocyte injury andinduce a minimalchange-like nephropathy (Yap et al., 1999; Cheung et al., 2004 and weiet al., 2005). Lai et al. (2007) reported that overexpression of IL-13 caused downregulation of nephrin, podocin, and dystroglycan-all of which are important molecules in maintaining SD integrity-and a concurrent upregulation of B7-1 as well as MCNSin a rat experiment model.

\section{Patients and methods:-}

Fifty blood samples of patients suffering from nephrotic syndrome during the period from September 2017 to January 2018 from the Al-Emamain Al-Kadhemain Medical City and Welfare Teaching Hospital in Medical City of Baghdad and twenty-five blood samples have been collected from unrelated healthy children. The age of NS patients was from 2 to 14 years with mean $7.78 \pm 3.52$ years and from 5 to 14 years with mean $8.64 \pm 3.08$ years for healthy control. Out of 50 cases, 35 cases (70\%) were males and 15 cases (30\%) were females and the male to female ratio was 2.3:1. Pathological types based on response to steroid nephrotic syndrome among patients revealed that 14 cases (28\%) steroid sensitive infrequent relapse (SSIFR), 12 cases (24\%) steroid sensitive frequent relapse (SSFR), 9 cases (18\%) steroid resistance (SR) and 15 cases (30\%) newly diagnosis (ND). The biochemical test was done to determine the levels of blood urea, serum creatinine, serum albumin and serum cholesterol in patients and healthy control. Serum IL-13 levels were detected for NS patients and healthy control by using R\&D ELISA kit.

The Statistical Analysis System- SAS (2012) program was used to study the effect of different factors in study parameters. Chi-square test was used to significantly compare between percentages and Least significant difference -LSD test (ANOVA) or T-Test was used to significantly compare between means. correlation coefficient was estimated between variablesin this study.

\section{Results:-}

Fifty children with NS compared to twenty-five healthy children as a control group were recorded in this study. Pathological types based on response to steroid nephrotic syndrome among patients revealed that 14 cases (28\%) steroid sensitive infrequent relapse (SSIFR), 12 cases (24\%) steroid sensitive frequent relapse (SSFR), 9 cases (18\%) steroid resistance (SR) and 15 cases (30\%) Newly diagnosis.

The mean level of serum albumin, serum creatinine and blood urea was significantly decreased in patients in compared with healthy control, while the mean level of urine albumin and serum cholesterol was significantly increased in patients in compared with healthy control. The results of mean IL-13 level in healthy serum (205.18 \pm $2.61 \mathrm{pg} / \mathrm{ml})$ was significantly lower than children with nephrotic syndrome $(335.50 \pm 40.68 \mathrm{pg} / \mathrm{ml})$ Table 1 .

Comparison between the IL-13 concentration among types of NS and healthy control demonstrated that insignificant difference between ND $(406.21 \pm 131.79 \mathrm{pg} / \mathrm{ml})$, SR $(290.40 \pm 25.27 \mathrm{pg} / \mathrm{ml})$, SSFR $(306.82 \pm 18.55 \mathrm{pg} / \mathrm{ml})$ and $\operatorname{SSIR}(313.31 \pm 33.75 \mathrm{pg} / \mathrm{ml})$ Figure 1.

There is a significant correlation between IL-13 serum concentration and serum albumin levels in nephrotic syndrome patients and no significant correlation with other biochemical parameters Table 2.

Table 1:-Compare between patients and control in IL-13 levels

\begin{tabular}{|c|c|}
\hline Group & IL-13 $(\mathbf{p g} / \mathbf{m l})$ Mean \pm SE \\
\hline Patients & $335.50 \pm 40.68$ \\
\hline Control & $205.18 \pm 2.61$ \\
\hline T-Test & $115.14 *$ \\
\hline P-value & 0.0271 \\
\hline \multicolumn{2}{|c|}{} \\
\hline
\end{tabular}




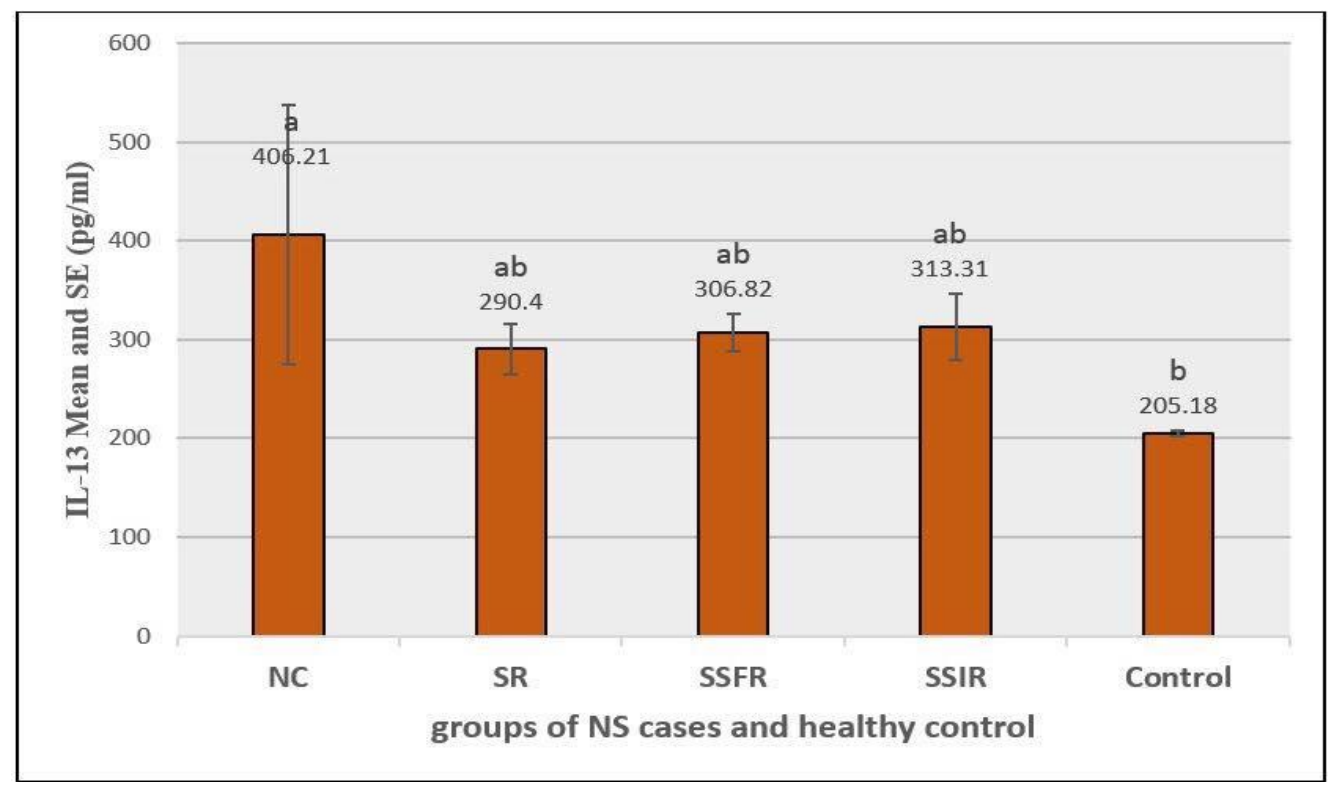

Figure 1:-Serum IL-13 levels among groups of NS and control

ND: Newly diagnosis, SR: steroid resistance, SSFR: Steroid sensitive frequent relapse, SSIR: Steroid sensitive infrequent relapse. Different letters mean significant differences between means at $\mathrm{P}<0.05$

Table 2:-Correlation between IL-13 and diagnostic features in patients

\begin{tabular}{|c|c|}
\hline Laboratory parameters for diagnosis NS & IL-13 \\
\hline Urea & $-0.06 \mathrm{NS}$ \\
\hline Creatinine & $-0.17 \mathrm{NS}$ \\
\hline Serum albumin & $-0.22 *$ \\
\hline Cholesterol & $0.08 \mathrm{NS}$ \\
\hline Urine albumin & $0.11 \mathrm{NS}$ \\
\hline Pus cell in urine HPF & $-0.07 \mathrm{NS}$ \\
\hline RBC in urine HPF & $-0.06 \mathrm{NS}$ \\
\hline$*(\mathrm{P}<0.05), \mathrm{NS}:$ Non-Significant. \\
\hline
\end{tabular}

\section{Discussion:-}

The increased of IL-13 in NS patients was in agreement with Mishra et al. (2014) who suggested that raised serum IL-13 in active phaseand normalization in remission, Greater concentration of urinary IL-13 in untreatednephrotic syndrome patients in comparison to healthy controls and the percentage of CD3+ IL-13-producingcells was significantly greater in relapsing nephroticsand reduced during remission. increased IL-13 mRNA expression in CD4+ and CD8+ in nephrotic relapse than remission. Cytokines receptors of IL-4 and IL-13 are expressed by podocytes in different glomerular diseases, increasing the potential that IL-13 might participate to the proteinuria pathophysiology (Zhang et al. 2011). Mamizadehet al. (2017) also reported that Level of serum IL-13 does not significantly drop after steroid therapy. higher concentration of serum IL-13 in children withacute minimal change disease (MCD) in comparison with a healthy control group. the raisedexpression of IL-13 by T-helper 2 cells in patients withacute nephrotic syndrome. Steroid can repress the IL-13production by CD4+ cells rather than byCD8+ T-lymphocyte.

IL-13 correlated with the induction of podocyte structuralalteration that are capable of changing thefiltration selectivity and causing nephrotic syndrome (Medrano et al. 2012). overexpression of IL-13 give rise to the downregulation ofpodocin, nephrin, and dystroglycan. These proteins are decisivemolecules in maintaining the integrity of slit diaphragm, and thesynchronous upregulation of CD80, IL-13R $\alpha 2$ and IL-4R $\alpha$ in IL-13 transfected rats (Kim et al. 2016). Park et al. (2015) demonstrated a redistribution and decrease in Zonula Occludens-1 (ZO-1) proteins from podocytes of human treated with IL-13. The ZO-1 molecules exposure to IL-13 caused ZO-1 to get about and accumulate inside toward the cytoplasmic actin filaments, suggesting that the watched redistribution and 
decrease in ZO-1 proteins could be involved in the nephrotic syndrome pathogenesis. IL-13 may change ZO-1 proteins expression, leading in proteinuria, and also supply an explanation for the sensible connection of T-helper 2 cytokines, minimal change nephrotic syndrome, and atopy.

IL-13prompt CD80 expression in podocytes, and CD80 is thekey mediator for prompting proteinuria. It is assumedthat NS has two steps: the first step israised serum IL-13 concentration and then CD80 in podocytes cytoplasmand the second step is inadequate CD80 silencingby deficient release of soluble CTLA-4 (cytotoxic Tlymphocyte-associated protein 4) (Mamizadehet al. 2017).

Nephrotic syndrome can begin with a raise in production of IL-13 but its remission may concern with CD80/CTLA4 ratio not on the serum IL-13 concentration. Additionally, the actionof IL-13 on podocytes may be local depending on the concentration of IL-13 in the zone and its receptors expression (Mamizadehet al. 2017).

Conclusion: we concluded that serum IL-13 levels was increased in NS patients in compared with healthy control, and the highly significant concentration of IL-13 was reported in newly diagnosis patients. we need more studies to determine the precise role of IL13 in the NS pathogenesis.

\section{References:-}

1. Bagga, A. and Mantan, M. (2005). Nephrotic syndrome in children. Indian J. Med. Res., 122(1):13-28.

2. Bahbah, M.; El Mashad, G.; Abdelnaby, S. and Azab, H. (2015). Serum immunoglobulin G, M and IgG:IgM ratio as predictors for outcome of childhood nephrotic syndrome. Menoufia medical J., 28: 431-436.

3. Cheung, W.; Wei, C.; Seah, C.; Jordan, S. and Yap, H. (2004). Atopy, serumIgE, and interleukin-13 in steroidresponsive nephrotic syndrome. Pediatr. Nephrol, 19: 627-632.

4. Eddy, A. and Symons, J. (2003). Nephrotic syndrome in childhood. The Lancet J., 362:629-639.

5. Kim, S.; Park, S.; Han, K.; Kronbichler, A.; Saleem, M.; Oh, J.; Lim, B. and Shin, J. (2016). Pathogenesis of minimal change nephrotic syndrome: an immunological concept. Korean J. Pediatr., 59(5): 205-211.

6. Lai, K.; Wei, C.; Tan, L.; Tan, P.; Chiang, G.; Lee, C. et al. (2007). Overexpression of interleukin-13 induces minimal-change-likenephropathy in rats. J Am SocNephrol, 18: 1476-1485.

7. Mamizadeh, N.; Otukesh, H.; Hoseini, R. and Moshfegh, F. (2017). Serum interleukin 13 level in steroid sensitive nephrotic syndrome. J comprped, 8(3): e12765.

8. Medrano, A.; Caceres C.; Via, A.; Perez, M.; Pamplona, I. and Roldan, E. (2012). Biological markers of nephrotic syndrome: a few steps forward in the long way. RevistaNefrologia, 32(5): 558-572.

9. Mishra, O.; Abhishek A.; Mishra, R.; Prasad, R. and Pohl, M. (2014). Can we predict relapses in children with idiopathic steroid-sensitive nephrotic syndrome?. Journal of tropical pediatrics, 59(5): 343-349.

10. Park, S.; Saleem, M.; Nam, J.; Ha, T. and Shin, J. (2015). Effects of Interleukin-13 and Montelukast on the Expression of Zonula Occludens-1 in Human Podocytes. Yonsei Med J, 56(2): 426-432.

11. Roy, R.; Roy, E.; Rahman, M. and Hossain, M. (2009). Serum immunoglobulin G, M and IgG:IgM ratio as predictors for outcome of childhood nephrotic syndrome. World J. Pediatr, 5(2):127-131.

12. Sahali, D.; Lang, P.; Guellaen, G. and Bensman, A. (2002). New insights about immunopathology of lipoid nephrosis. Bull Acad. Natl. Med.,186:683-690.

13. SAS. (2012). Statistical Analysis System, User's Guide. Statistical. Version 9.1th ed. SAS. Inst. Inc. Cary. N.C. USA.

14. Vries, J. (1998). The role of IL-13 and its receptor in allergy and inflammatory responses. J. Allergy Clin. Immunol., 102(2): 165-169.

15. Wei, C.; Cheung, W.; Heng, C.; Arty, N.; Chong, S.; Lee, B.; et al. (2005). Interleukin-13 genetic polymorphisms in Singapore Chinese children correlate with long-term outcome of minimal-change disease. Nephrol Dial Transplant, 20: 728-734.

16. Yap, H.; Cheung, W.; Murugasu, B.; Sim, S.; Seah, C. and Jordan, S. (1999). Th1 and Th2 cytokine mRNA profles in childhood nephrotic syndrome: evidence for increased IL-13 mRNA expression in relapse. J Am SocNephrol, 10: 529-537.

17. Zhang, S.; Audard, V.; Fan, Q.; Pawlak, A.; Lang, P. and Sahali, D. (2011). Immunopathogenesis of idiopathic nephrotic syndrome. Contributions to Nephrology, 169:94-106. 